Available online at

\title{
Performance Analysis Of "Toga" Foundation with Cap on Thick Soft Soil Based on Laboratory Models and Finite Element Analysis
}

\author{
M. Kurnia ${ }^{1^{*}}$, P. P. Rahardjo ${ }^{2}$ \\ ${ }^{*}$ Department of Civil Engineering, Parahyangan Catholic University. \\ 2Lecturer in Department of Civil Engineer, Parahyangan Catholic University. \\ E-mail: ${ }^{\text {* }}$ melissakurnia0896@gmail.com
}

\begin{tabular}{ll} 
A R T I C L E I N F O \\
\hline Article History : \\
Article entry $\quad: 07-09-2020$ \\
Article revised $: 24-09-2020$ \\
Article received & $: 13-10-2020$ \\
\hline
\end{tabular}

Keywords :

Soft Soils, "Toga" Foundation, Analysis, Finite Element Analysis

IEEE Style in citing this article : [11] W. Zheng, F. Tao, and F. Guangxiu, "Study of the Construction Technology of Caisson under Complex Geological Conditions," J. Phys. Conf. Ser., vol. 1168, no. 2, 2019, doi: $10.1088 / 1742-$ 6596/1168/2/022063.

\begin{abstract}
A B S T R A C T
Various alternative foundations are offered depending on soil conditions from the results of soil investigations. In difficult soil types such as thick, soft soil layers, pile foundation is generally used to avoid the excess settlements, but deep foundations for small buildings are not the right solution when viewed from a cost perspective. One of the more economical foundations is to use the"toga" foundation, with a plate on top and a caisson underneath where the caisson can be inserted into the soil with an open end. Through this study, the carrying capacity of "toga" foundation will be analyzed. Then the foundation will be made on a laboratory scale and tested with axial load. The load and deformation relationship were analyzed using PLAXIS 3D analysis. It can be concluded the performance of the "toga" foundation on thick soft soil can be used for two-floored buildings.
\end{abstract}

\section{Introduction}

Various alternative foundations are offered depending on the soil conditions from the results of soil investigations. The type of foundation used can be a shallow foundation or a deep foundation depending on the soil conditions and the amount of load working on the foundation. In thick, soft soil layers, pile foundations are generally used to be transferred to a better soil layer. The building load can transfer into the foundation and without causing excessive building 
settlements. However, the use of pile foundations in Low-rise buildings are less than optimal from the cost point of view. In a housing construction project on a thick layer of soft soil (> 15 $\mathrm{m})$, other alternatives are needed besides a pile foundation to save construction costs but still meet the construction safety requirements (the load received should not exceed the bearing capacity of the soil, so that shear failure does not occur). One of the newest, an economical alternative idea is to use a toga foundation.

The soil used for the laboratory test model is taken from Pantai Indah Kapuk 2 area, North Jakarta. This research only examines the foundation's behavior on soft soil in the form of clay or silt so that fill material such as red soil (laterite soil), sandy soil, and gravel are set aside. In laboratory-scale experiments, the chosen soil is mixed by kneading it by hand or being trampled. After mixing evenly and ensuring that the soil is homogeneous enough, samples are taken for laboratory tests to produce soil parameters for analysis purposes. The area of study located on Pantai Indah Kapuk 2 area, North Jakarta, can be seen from Figure 1 below:

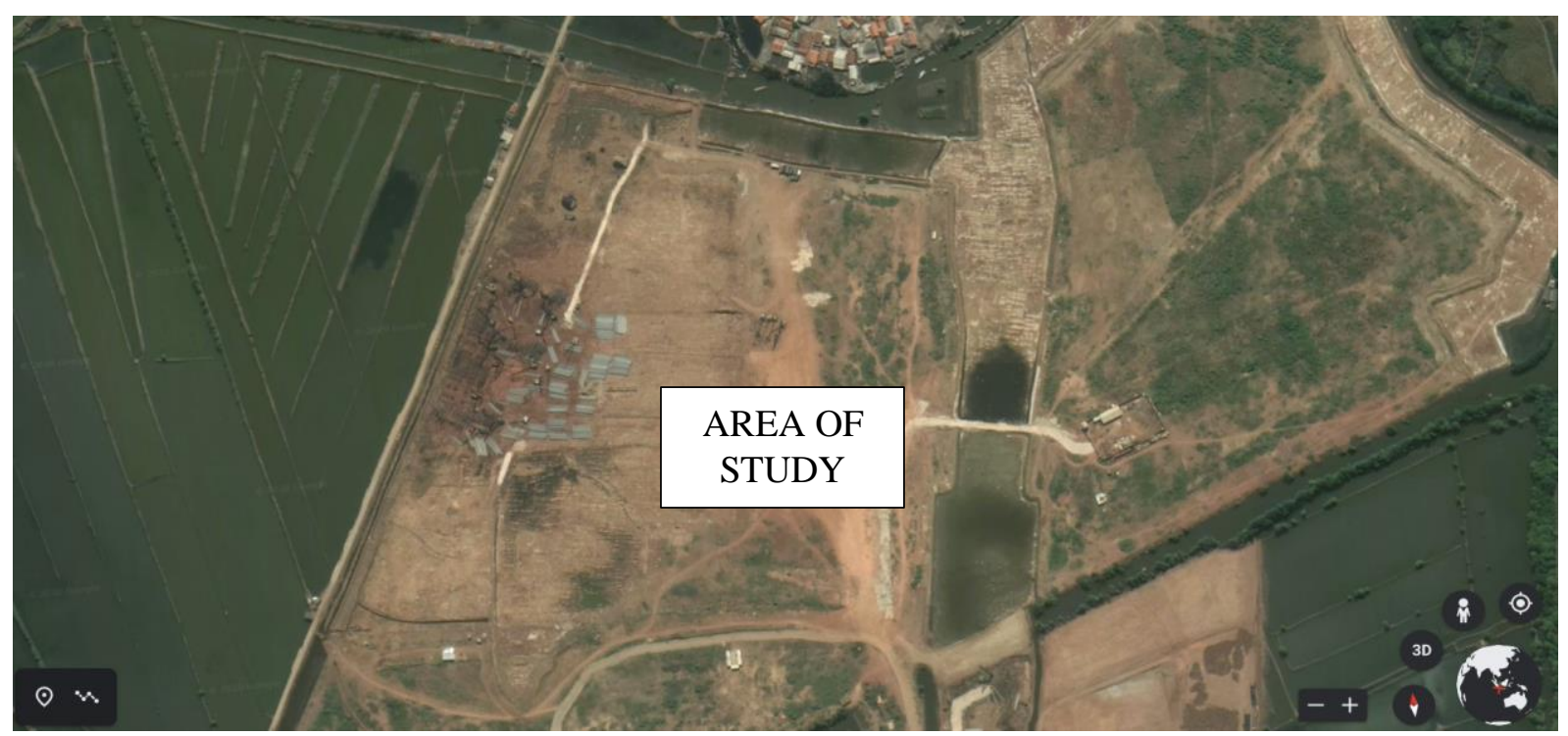

Source : Google Earth.

Figure 1. Area of Study

\section{Literature Review}

One of the alternatives usually used for thick, soft soil is piled rafts [1]. Piled rafts provide an economical foundation option when an unpiled raft does not satisfy the design requirements [2]. But for piled raft, there are some unfavorable circumstances such as soil profile containing soft clays near the surface. In soft clays soil profile cases, the piled-raft may not be able to provide significant load capacity and stiffness [3]. Besides, piles are still used for 
construction on thick, soft soil. Therefore it's still not considered an economical foundation option for low-rise buildings ( $1-2$ floors). The other alternative is using a vacuum preloading with prefabricated vertical drain for soil improvement [4],[5], but for soft soils above $15 \mathrm{~m}$ not only it's not economical, this method also requires quite sometime before construction can even begin.

The Toga foundation is created by Rahardjo on research progress and discussed inclass instruction and software development, namely Caisson [6],[7]. Toga foundation is a caisson with a pile cap taken into account for soil reaction. The shape of the toga foundation that the authors will discuss resembles a graduation cap's shape, with a plate on top and a caisson at the bottom, but the bottom part of the caisson is left open. It can consider caisson as the cylindrical communal structure with a large diameter and rigid. The caisson's shape looked like an open caisson type, with the material of caisson already prefabricated before installation [8] [16]. The caisson is filled with soil to obtain skin friction of the outer and inner caisson. The plates on the foundation will be placed on good quality soil to provide additional bearing capacity by distributing the load of the building to the embankment soil above soft soil and resisting the moments and lateral forces that occur so as to minimize the amount of displacement and rotation of the stiff caisson foundation on soft soil. Can see a Sketch of the toga foundation for the large-scale model in Figure 2.

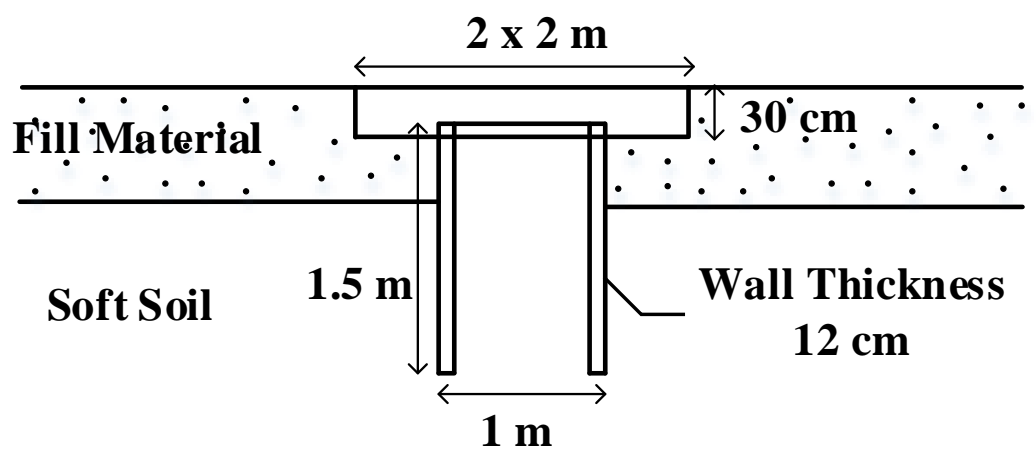

Source : Analysis Results

Figure 2. Toga Foundation Sketch (Large-Scale Model)

\section{Research Method}

The research method will start from the literature study of shallow foundations, caisson foundations, analysis of the foundation's bearing capacity, and analysis of foundation settlements. Then, determine the dimensions of the test foundation and the box model's dimensions for small-scale laboratory models. Obtained soil samples used for the laboratory 
test model from the PIK 2 area, North Jakarta. Soil samples are then taken for laboratory tests to obtain parameter data for analysis. In parallel, Obtained a compressive axial loading test on a laboratory scale test model and obtained a graph of the load and settlement relationship. The parameters obtained from the laboratory test are then processed using the three-dimensional analysis program PLAXIS 3D. The settlement obtained is compared with the results of the axial compression loading test of the test foundation. In the PLAXIS 3D program, large-scale foundation models are also modeled for the toga foundation in undrained and drained conditions. They can see a sketch of the toga foundation for the laboratory-scale model in Figure 3. The pile cap thickness is $1 \mathrm{~cm}$, with the pile cap area of $30 \times 30 \mathrm{~cm}$. The caisson has $20 \mathrm{~cm}$ length with $10 \mathrm{~cm}$ diameter and wall thickness $0.8 \mathrm{~cm}$. Can see the box model for the laboratory-scale test in Figure 4. The box's length is $150 \mathrm{~cm}$, the width of the box is $30 \mathrm{~cm}$, and the height of the box is $55 \mathrm{~cm}$.

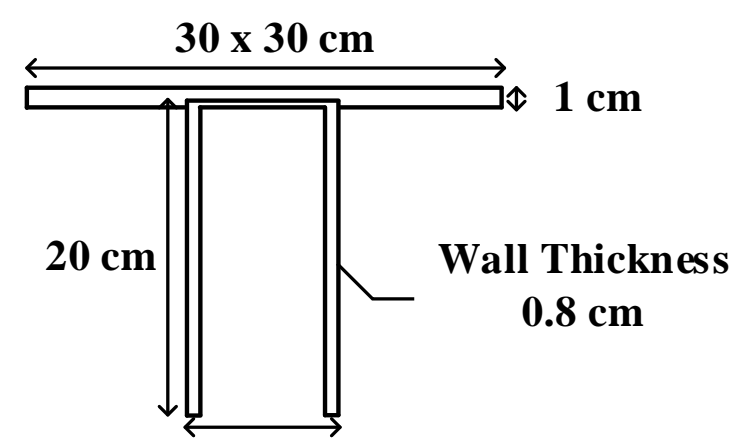

$10 \mathrm{~cm}$

Source : Analysis Results

Figure 3. Toga Foundation Sketch (Laboratory-Scale Model)

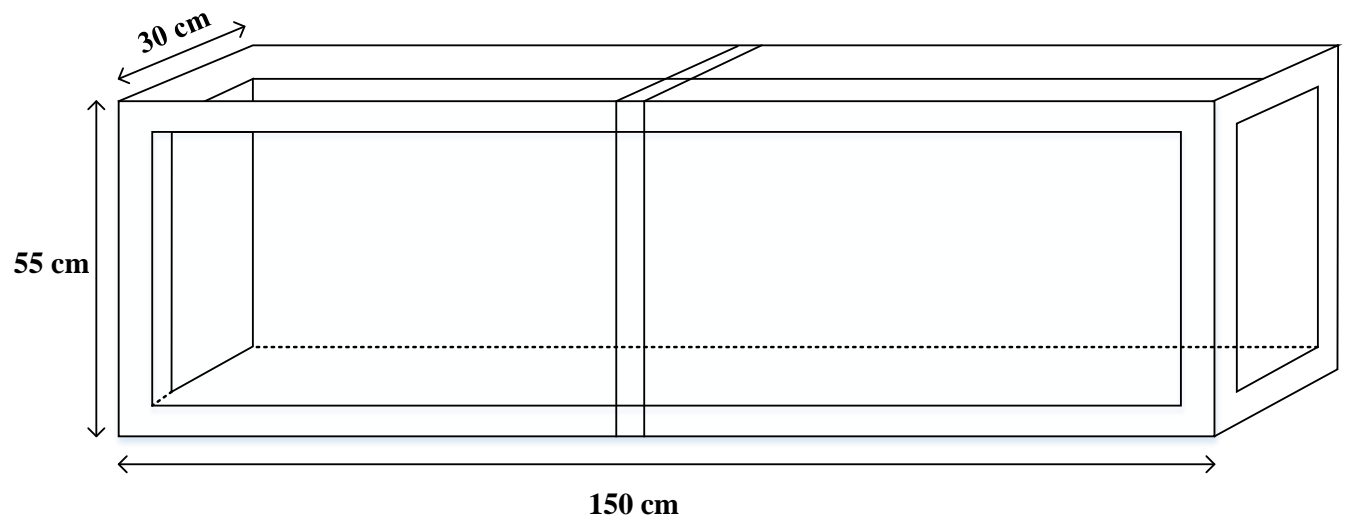

Source : Analysis Results

Figure 4. Box Model For Laboratory-Scale Test 


\subsection{Description and Technical Specifications}

The disturbed soil is "rearranged" in the box without being pressed. Every $5 \mathrm{~cm}$, the soil layer is applied with flour at the front of the box so that the failure surface can be easily seen when the soil is loaded. Then spread the sand $6 \mathrm{~cm}$ thick above the soft soil layer. Sand models embankment soil that functions as a good soil layer, which will add bearing capacity to the foundation plate. Can see the box model that has been filled with disturbed soil in Figure 5. After that, the soil deformation due to the soil being "rearranged" can be measured with dials that were placed in the left, middle, and right part of the box model. Soil deformation measured can be plotted against time to make a graph shown in Figure 6 due to the soil being "rearranged".

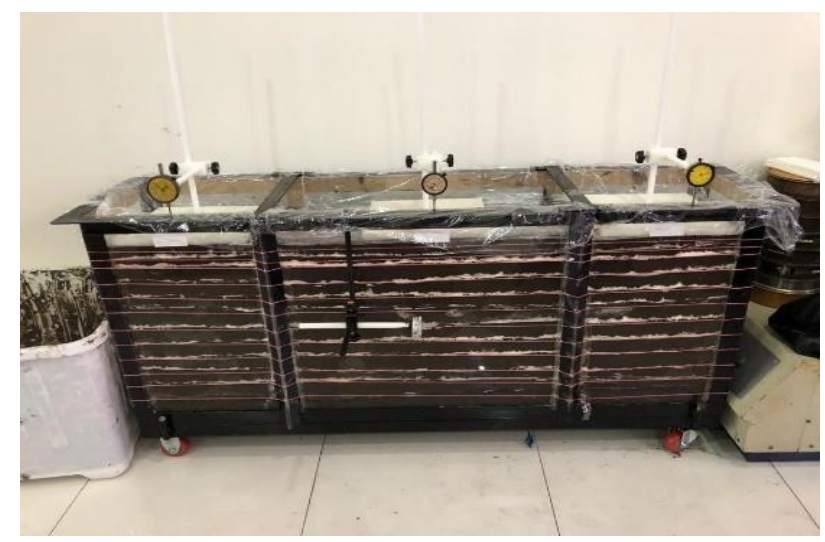

Source: Author's Documentation.

Figure 5. Soil That Has Been "Rearranged" Is Allowed To Be Settled And The Settlement Can Be Measured

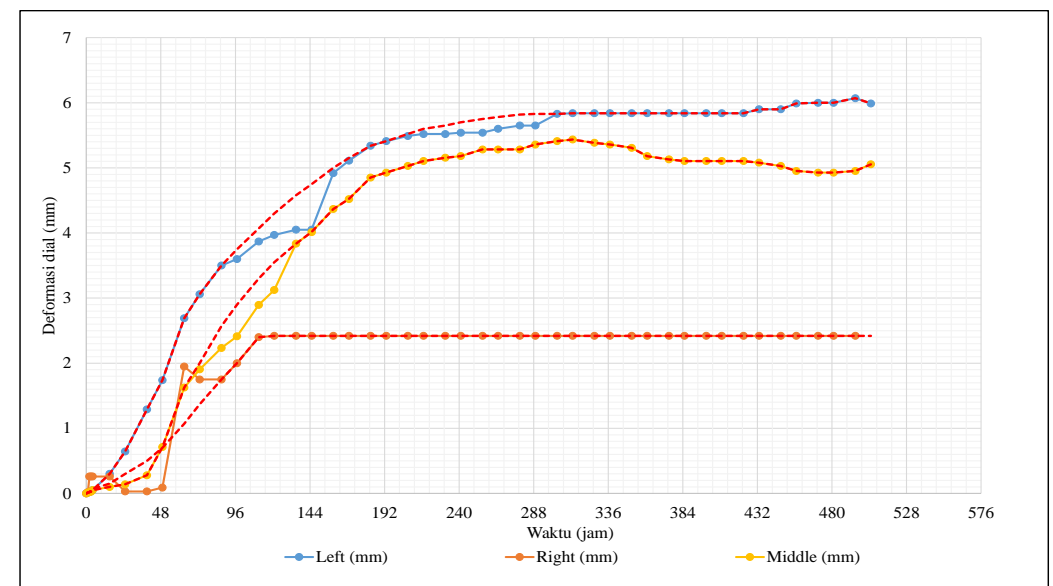

Source : Analysis Results

Figure 6. Soil Deformation Curve Against Time Due to The Soil Being "Rearranged"

Performance Analysis Of "Toga" Foundation with Cap on Thick Soft Soil Based on Laboratory Models and Finite Element 
After that, the soil is allowed to settle for \pm 3 weeks until the deformation curve flattens. It can start after the soil is allowed to settle down, the loading test on the test foundation. First, calculated the bearing capacity of the laboratory-scale model pile cap and the caisson's bearing capacity as the base for maximum load allowable for the axial load compression test [17][19]. Following ASTM D1143-07 rules regarding compressive axial loading methods, the rate of increasing or decreasing axial motion shall not be more than $0.25 \mathrm{~mm} / \mathrm{hr}$ [20].

The soil sample taken is already disturbed. Therefore it is necessary to carry out a laboratory test again to get soil parameters. The soil sample that has been taken will be tested for water content, specific gravity test, soil natural density test, Falcone penetrometer test, sieve analysis and hydrometer test, and the TX-CU test [21][24]. From the test results, the soil parameters that will be used for analysis are as shown in Table 1:

Table 1. Soil Parameter Undrained Condition for Laboratory-Scale Model

Soil Parameter Undrained Condition

\begin{tabular}{|c|c|c|c|c|c|c|c|}
\hline Cluster & tipe & $\begin{array}{c}\gamma \\
\left(\mathrm{kN} / \mathrm{m}^{3}\right)\end{array}$ & $\gamma$ sat $\left(\mathrm{kN} / \mathrm{m}^{3}\right)$ & $\begin{array}{c}\mathrm{c} \\
\left(\mathrm{kN} / \mathrm{m}^{2}\right)\end{array}$ & $\varphi\left({ }^{\circ}\right)$ & $v^{\prime}$ & $\begin{array}{c}E^{\prime} \\
\left(\mathrm{kN} / \mathrm{m}^{2}\right)\end{array}$ \\
\hline Sand & Drained & 16 & 17 & 0 & 28 & 0,3 & 5000 \\
\hline Clayey Silt & Undrained & 14,4 & 14,4 & 6 & 0 & 0,3 & 110 \\
\hline Concrete & & 24 & & - & - & 0,15 & 21000000 \\
\hline
\end{tabular}

Source : Analysis Results

For real-scale modeling using the original soil data around the PIK 2 area, North Jakarta. The soil parameters that will be used for analysis are as shown in Table 2:

Table 2. Soil Parameter Undrained and Drained Condition for Large-Scale Model Soil Parameter Undrained Condition

\begin{tabular}{|c|c|c|c|c|c|c|c|}
\hline Cluster & tipe & $\gamma\left(\mathrm{kN} / \mathrm{m}^{3}\right)$ & $\gamma$ sat $\left(\mathrm{kN} / \mathrm{m}^{3}\right)$ & $\mathrm{c}\left(\mathrm{kN} / \mathrm{m}^{2}\right)$ & $\left.\rho^{\varphi}\right)$ & $\mathrm{v}^{\prime}$ & $\mathrm{E}^{\prime}\left(\mathrm{kN} / \mathrm{m}^{2}\right)$ \\
\hline Sand & Undrained & 16 & 17 & 66 & 0 & 0,3 & 2450 \\
\hline Clay & Undrained & 14 & 15 & 10 & 0 & 0,3 & 1470 \\
\hline Concrete & & 24 & & - & - & 0,15 & 21000000 \\
\hline \multicolumn{8}{|c|}{ Soil Parameter Undrained Condition } \\
\hline Cluster & tipe & $\gamma\left(\mathrm{kN} / \mathrm{m}^{3}\right)$ & $\gamma$ sat $\left(\mathrm{kN} / \mathrm{m}^{3}\right)$ & $\mathrm{c}\left(\mathrm{kN} / \mathrm{m}^{2}\right)$ & $\begin{array}{c}\varphi \\
\left(^{\circ}\right)\end{array}$ & $v^{\prime}$ & $\mathrm{E}^{\prime}\left(\mathrm{kN} / \mathrm{m}^{2}\right)$ \\
\hline Clay & Drained & 16 & 17 & 0 & 26 & 0,3 & 2450 \\
\hline Clay & Drained & 14 & 15 & 13 & 26 & 0,3 & 1470 \\
\hline Concrete & & 24 & & - & - & 0,15 & 21000000 \\
\hline
\end{tabular}

Source : Analysis Results 


\section{Results and Discussions}

According to the axial compression loading test result shown in Figure 7, at $0.72 \mathrm{kN}$ load, the foundation has a large settlement, which means that there has been a shear failure at the load of $0.72 \mathrm{kN}$. PLAXIS 3D analysis is then carried out on the toga foundation model, where the bottom part of the caisson is opened (laboratory test model scale) [25], [26].

\section{Ultimate Bearing Capacity Interpretation}

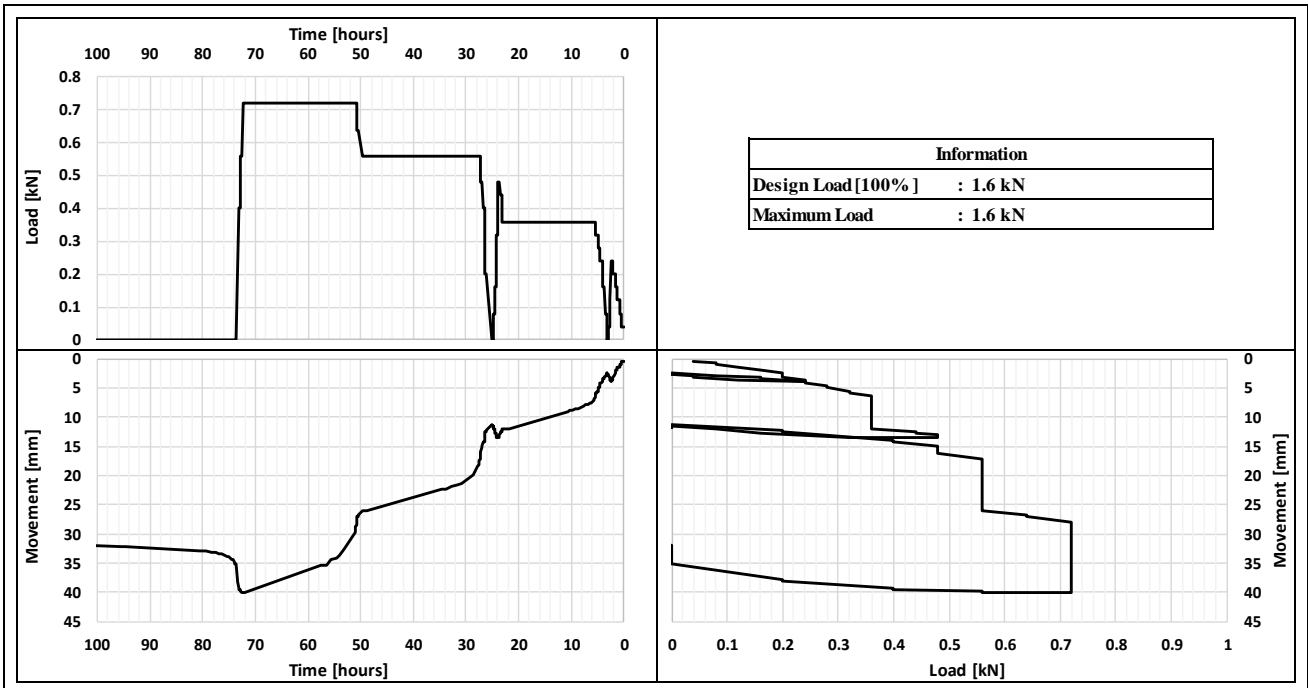

Source : Analysis Results

Figure 7. Soil Deformation Measured by Dial

Following are the results of the PLAXIS 3D analysis for laboratory test model scale:

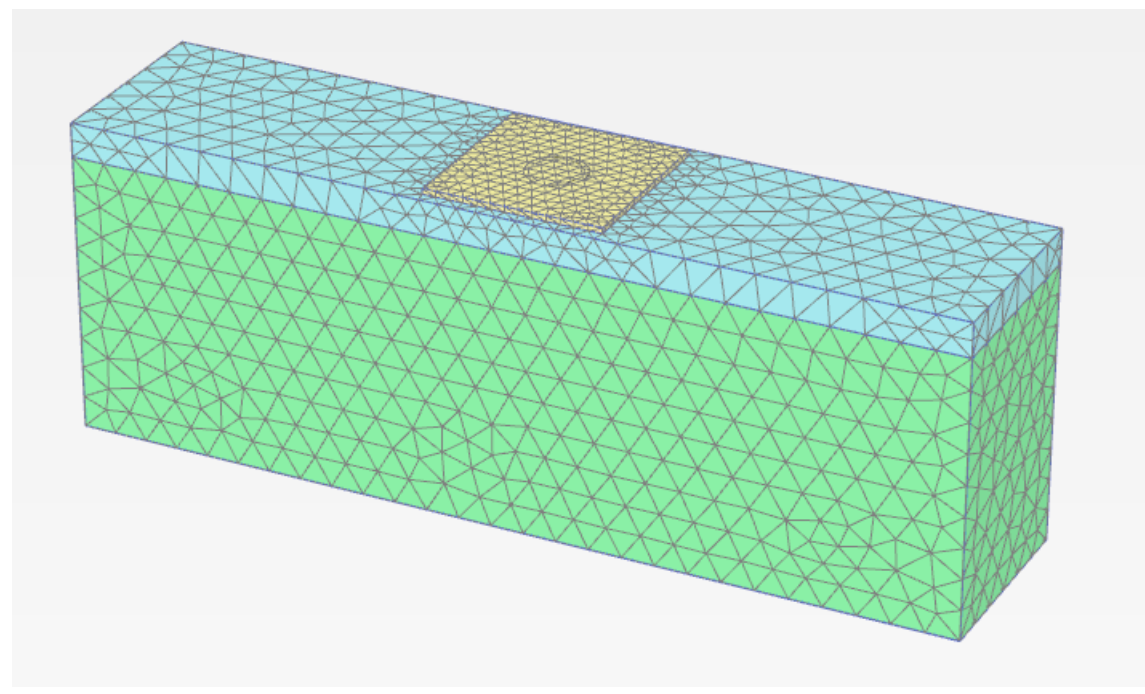

Source : Analysis Results

Figure 8. Toga Foundation Mesh (Laboratory Test Model Scale) 
Figure 8 shown the meshing of the toga foundation model. The model was given a load of $0.72 \mathrm{kN}(8 \mathrm{kPa})$ after the meshing process, and the maximum load carried out on the axial compression loading test. The analysis result is shown in Figure 9, with a settlement of $15.90 \mathrm{~mm}$ for undrained conditions. The analysis is then performed by carrying out different loads in order to obtain a graph (load vs. settlement of toga foundation for laboratory test model scale in undrained condition) so that can compare the graph to compressive axial load test results on the test toga foundation model which was shown on Figure 10.

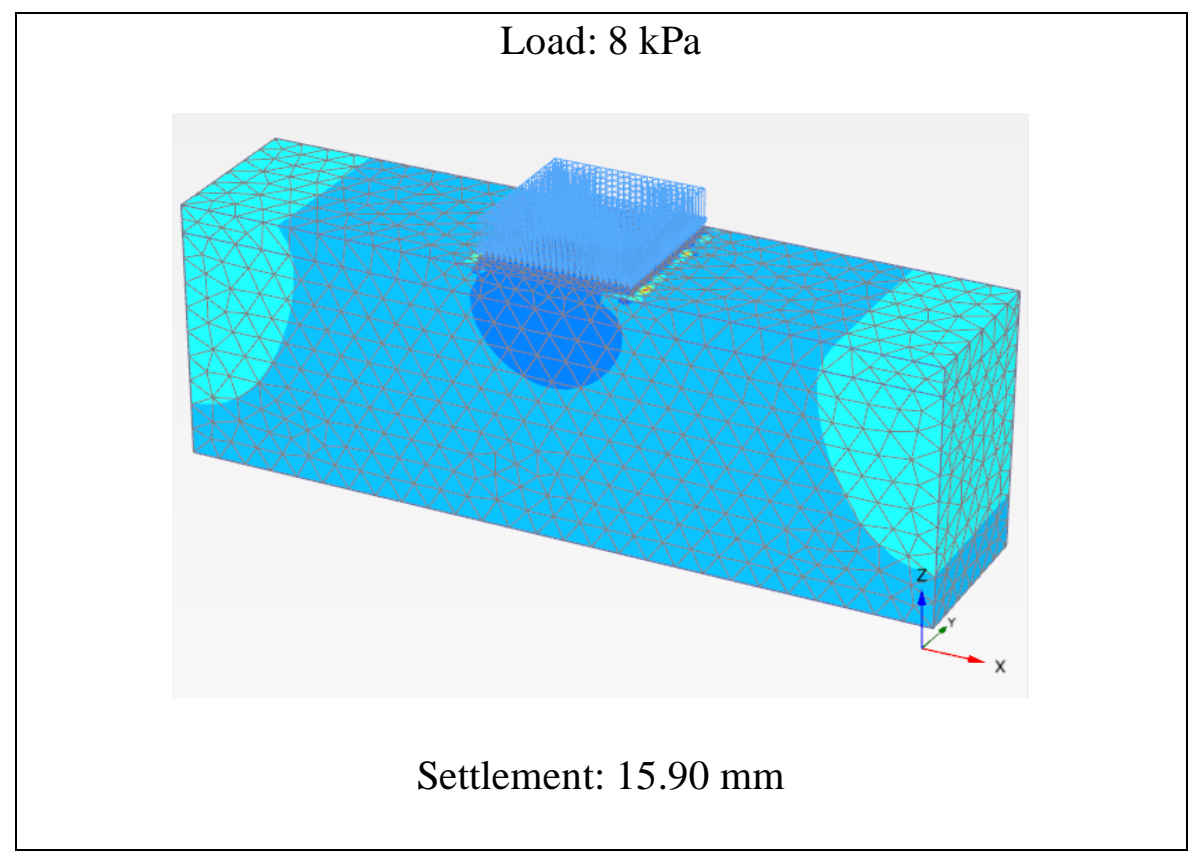

Source : Analysis Results

Figure 9. Toga Foundation Model Failure Surface (Laboratory Test Model Scale) Undrained Condition $8 \mathrm{kPa}$ Load 


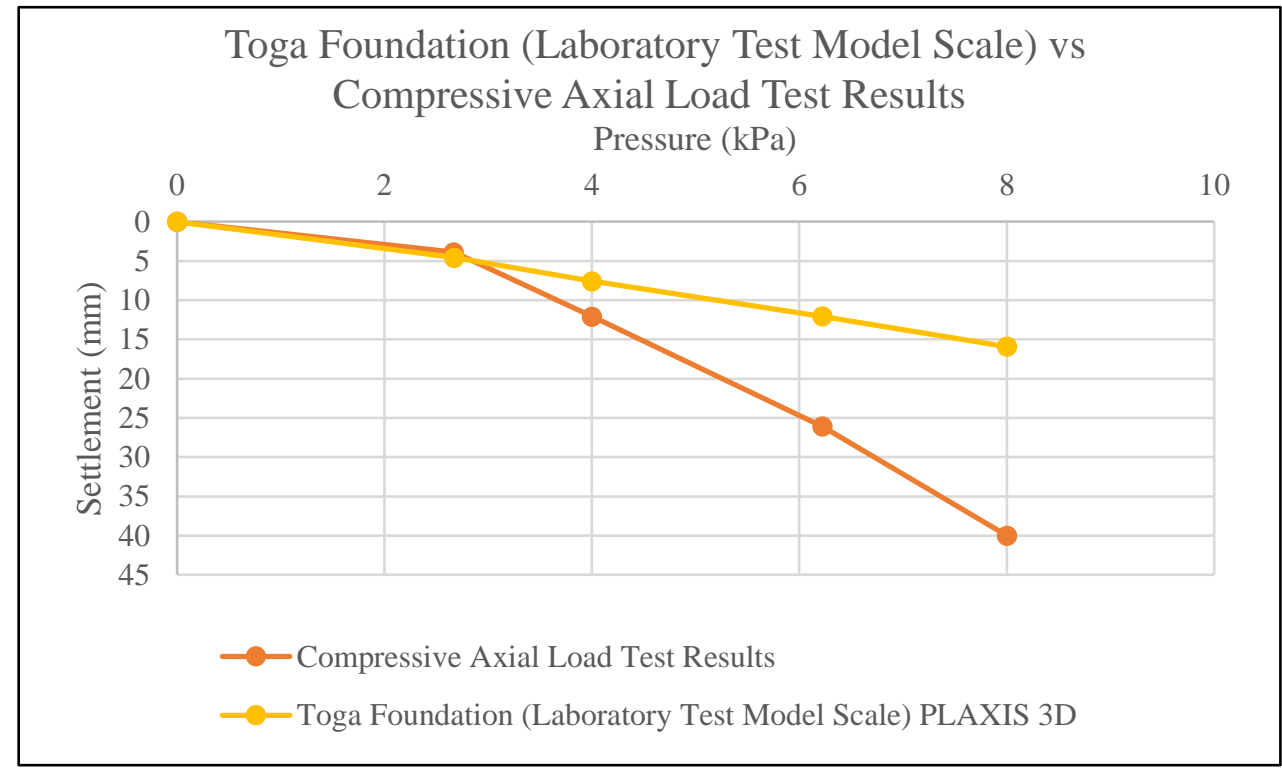

Source : Analysis Results

Figure 10. Graph of Load vs Settlement of Toga Foundation (Laboratory Test Model Scale) Undrained Condition and Compressive Axial Load Test Results on the Test Toga Foundation Model

Following are the results of the PLAXIS 3D analysis carried out on the toga foundation model where the bottom part of the caisson is opened (large-scale model):

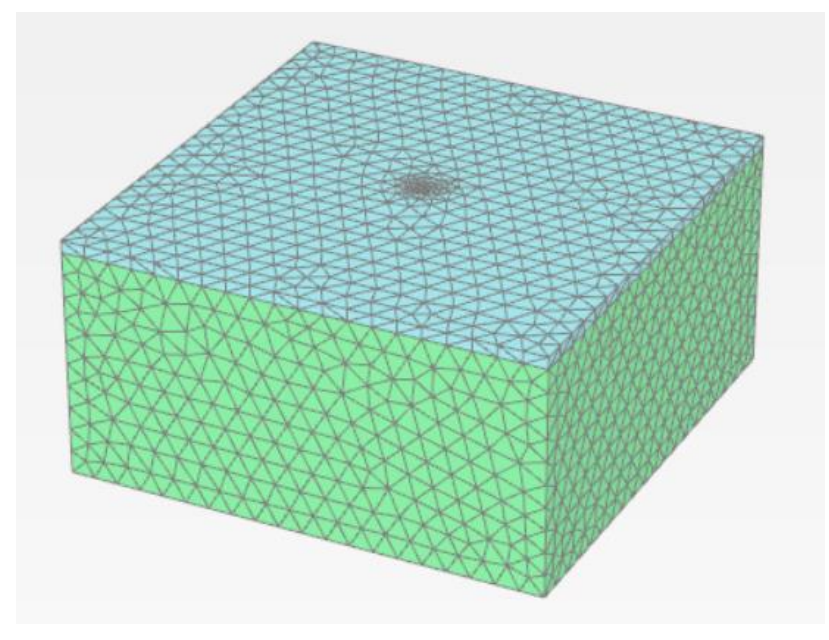

\section{Source : Analysis Results}

Figure 11. Toga Foundation Mesh (Large-Scale Model)

The same analysis was done for a large-scale toga foundation model. In Figure 11. shown the meshing of the toga foundation model. After the meshing process, the model was given a load of $500 \mathrm{kN}$. The analysis result is shown in Figure 12 with a settlement of 104.7 $\mathrm{mm}$ for the undrained condition and $152.22 \mathrm{~mm}$ for the drained condition. The analysis is then 
performed by carrying out different loads to obtain a graph (load vs settlement of toga foundation for large-scale model) in both undrained and drained condition so that the graph can be compared, shown in Figure 13.

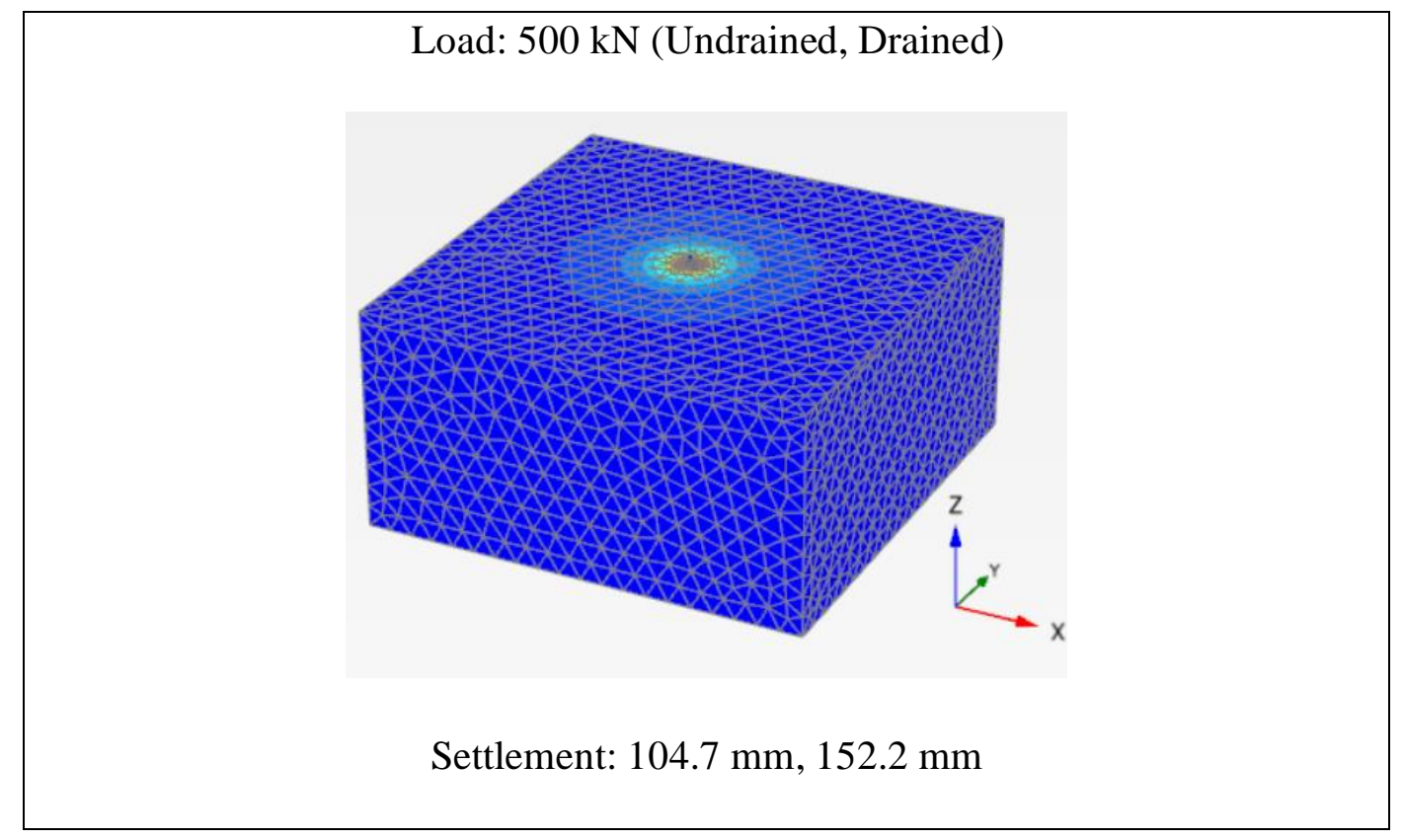

Source : Analysis Results

Figure 12. Toga Foundation Model Failure Surface (Large-Scale Model) Undrained and Drained Condition

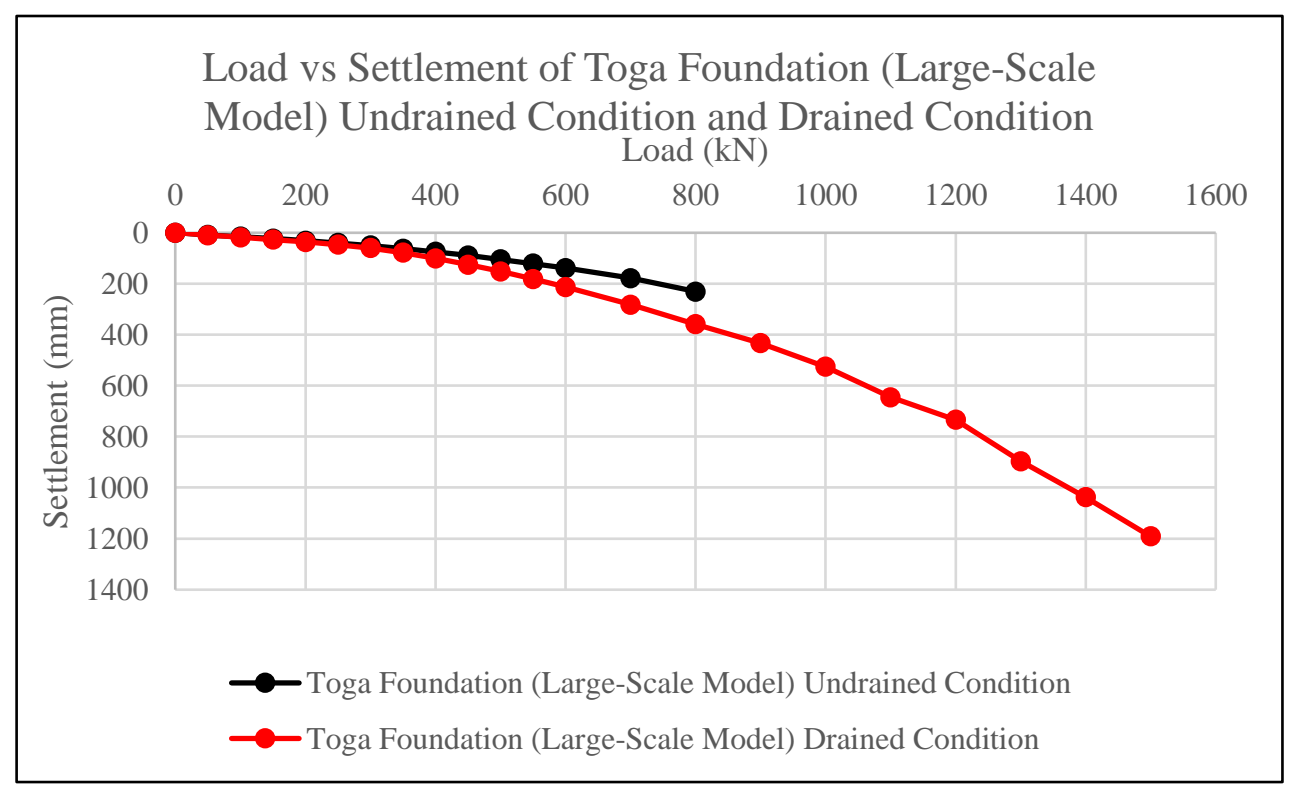

Source : Analysis Results

Figure 13. Graph of Load vs. Settlement of Toga Foundation (Large-Scale Model) Undrained Condition and Drained Condition 
From the results of the PLAXIS 3D analysis, and interpretation was carried out to obtain an estimate of the ultimate bearing capacity of the large-scale toga foundation using the Mazurkiewich method [27]-[29]. The ultimate capacity of the toga foundation is $900 \mathrm{kN}$ for undrained conditions (Figure 14 (a)) and $1900 \mathrm{kN}$ for drained conditions (Figure 14 (b)).

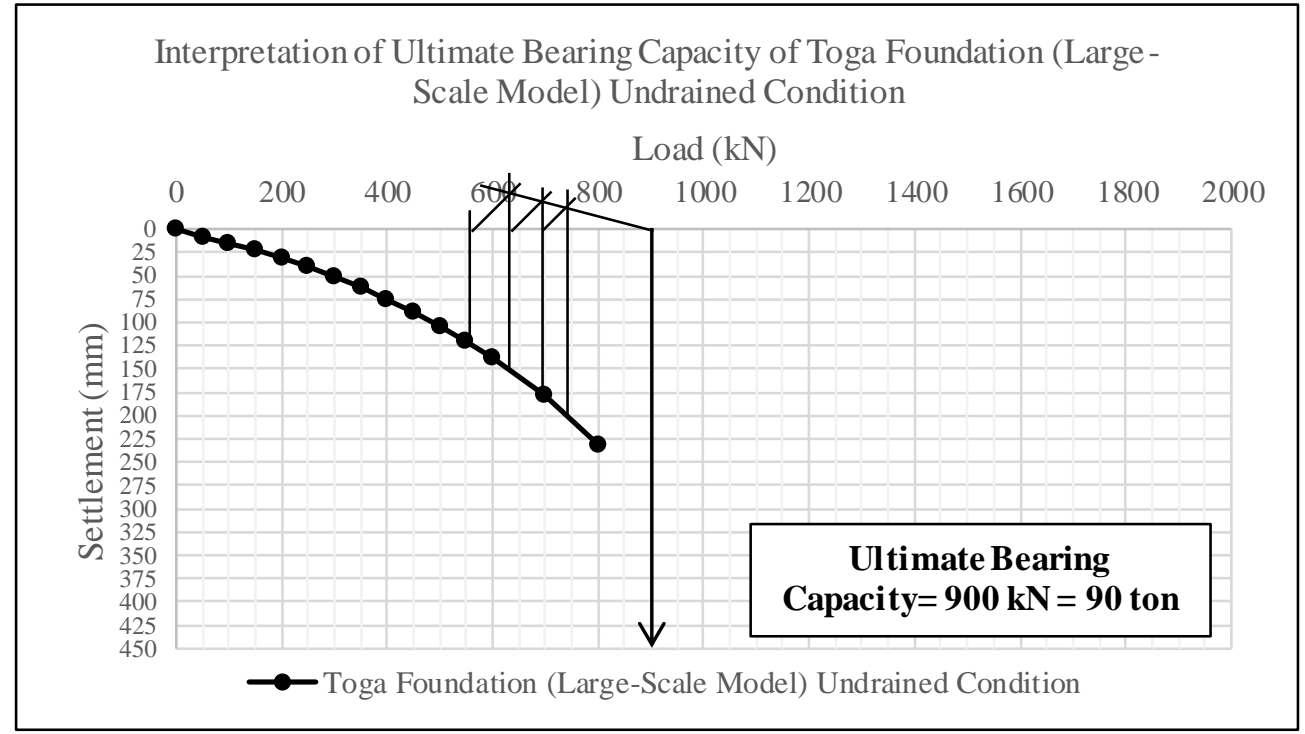

(a)

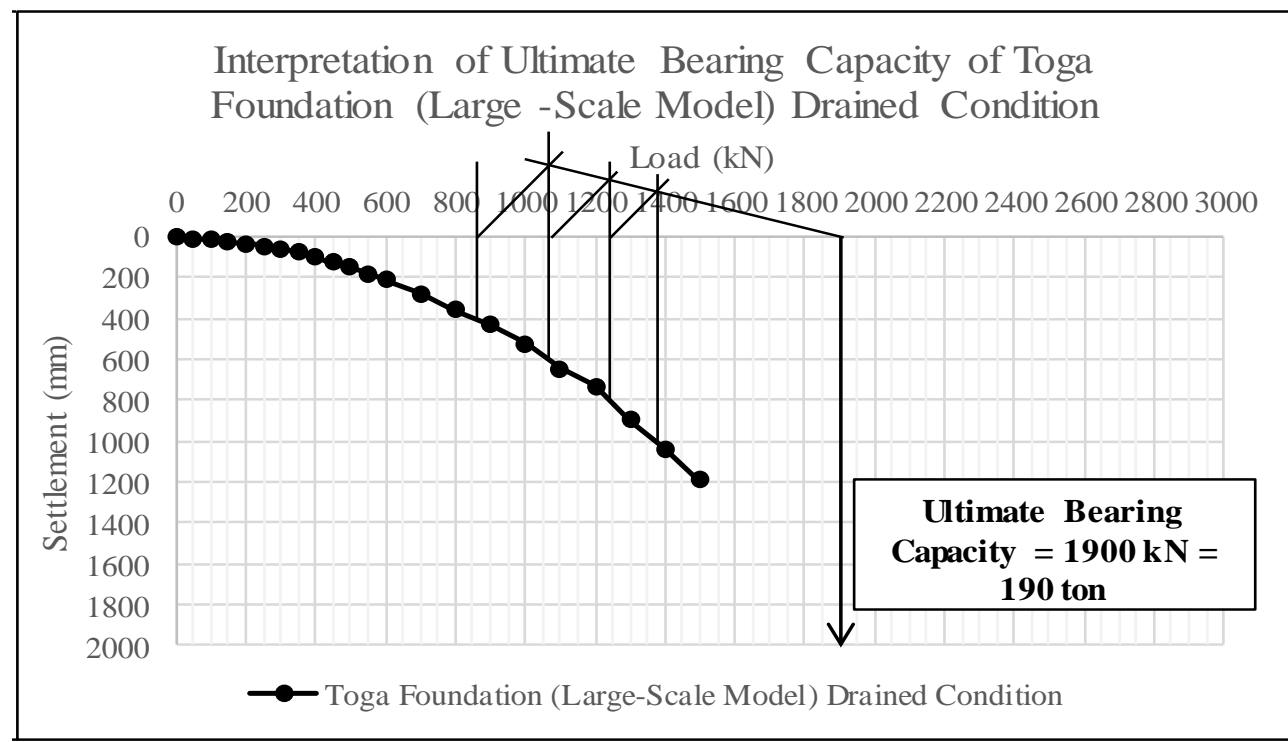

(b)

Source : Analysis Results

Figure 14. Interpretation of Ultimate Bearing Capacity of Toga Foundation (a) Undrained Condition and (b) Drained Condition by Mazurkiewich Method 


\section{Conclusion and Suggestion}

\subsection{Conclusion}

1. Toga foundation is a development for a new foundation model that is intended to solve foundation problems in soft soil.

2. Toga pile cap provides an additional contribution of carrying capacity.

3. From the results of the compressive axial load test on the test foundation model, the ultimate bearing capacity is $0.72 \mathrm{kN}$ on the toga foundation. In practice, the ultimate capacity on the test toga foundation is $8 \mathrm{kN} / \mathrm{m} 2$.

4. From the analysis results using the PLAXIS 3D program, the ultimate capacity of the toga foundation is $900 \mathrm{kN}$ for undrained conditions and $1900 \mathrm{kN}$ for drained conditions.

5. The toga foundation model obtained numerically has a higher bearing capacity than the toga foundation tested in real terms on a small scale.

\subsection{Suggestion}

1. It is advisable to carry out testing on a real full-scale model.

2. The reduction obtained from the lab test is different from the decrease obtained from the PLAXIS 3D analysis. This is probably due to unpredictable pore pressure when the foundation installation is carried out (where the foundation is installed by being pressed and was waited only one day before the loading test is carried out). Therefore it is necessary to measure the pore pressure in future studies. 


\section{References}

[1] J. O’Brien A., Burland, "Piles and Piled Rafts," ICE Man. Geotech. Eng. (C) 2012 Inst. Civ. Eng., no. January 2012, pp. 853-885, 2012, doi: 10.1680/moge.57098.0853.

[2] J. T. DeJong, M. B. Fritzges, and K. Nüsslein, "Particle shape effects on packing density,stiffness, and strength:natural and crushed sands," J. Geotech. Geoenvironmental Eng. (C) ASCE / DECEMBER 2006, vol. 132, no. 5, pp. 1600-1610, 2006, doi: 10.1061/(ASCE)1090-0241(2006)132.

[3] J. M. Raut, S. R. Khadeshwar, S. P. Bajad, and M. S. Kadu, "Simplified design method for piled raft foundations," Adv. Soil Dyn. Found. Eng. GSP 240 (C) ASCE 2014, no. 240 GSP, pp. 462-471, 2014, doi: 10.1061/9780784413425.047.

[4] V. A. Sakleshpur, M. Prezzi, and R. Salgado, "Ground engineering using prefabricated vertical drains: A review," Geotech. Eng. J. SEAGS AGSSEA Vol. 49 No. 1 March 2018 ISSN 0046-5828, vol. 49, no. 1, pp. 45-64, 2018.

[5] T. B., "Application of Prefabricated Vertical Drain in Soil Improvement," Civ. Eng. Dimens. Vol. 14, No. 1, vol. 14, no. 1, pp. 51-56, 2012, doi: 10.9744/ced.14.1.51-56.

[6] P. P. Rahardjo, "Perhitungan Kaison dengan Metoda Vallabhan," Short Course Pile Found., 1992.

[7] F. Vallabhan.CVG,Alikhanlou, "Short Rigid Piers in Clay," Proceeding ASCE, J. Geotech. Eng. Div., 1982.

[8] N. Darga Kumar and S. Narasimha Rao, "Earth pressures on caissons in marine clay under lateral loads - A laboratory study," Appl. Ocean Res., vol. 32, no. 1, pp. 58-70, 2010, doi: 10.1016/j.apor.2010.04.003.

[9] B. K. Gupta and D. Basu, "Soil resistances for laterally loaded rigid piles in multi-layered elastic soil," Geomech. Geoengin. An Int. J., vol. 15, no. 1, pp. 10-28, 2020, doi: $10.1080 / 17486025.2019 .1601267$

[10] J. D. García-Espinel, R. Alvarez-García-Lubén, J. M. González-Herrero, and D. CastroFresno, "Design and construction methods of caisson-type maritime infrastructures using GFRP,” J. Compos. Constr. (C) ASCE, pp. 1-10, 2015, doi: 10.1061/(ASCE)CC.19435614.0000591.

[11] W. Zheng, F. Tao, and F. Guangxiu, "Study of the Construction Technology of Caisson

Performance Analysis Of "Toga" Foundation with Cap on Thick Soft Soil Based on Laboratory Models and Finite Element 
under Complex Geological Conditions,” J. Phys. Conf. Ser., vol. 1168, no. 2, 2019, doi: $10.1088 / 1742-6596 / 1168 / 2 / 022063$.

[12] "Caisson Foundation - Types of Caisson Foundation." https://dailycivil.com/caissonfoundation-types-of-caisson-foundation/.

[13] J. E. Bowles, Foundation Analysis and Design, 3rd Editio. Book Company, New York, pp. 705-731, 1982.

[14] M. J. Tomlinson, Foundations Design and Construction, 6 th Edition. Pearson Education Ltd., Essex. pp. 214 - 264, 1995.

[15] M. J. Tomlinson, Foundation Design and Construction, 4th edition. Pitman Publishing Ltd. pp. $318-371$.

[16] L. Zeevaert, Foundation engineering for difficult subsoil condition. New York, N.Y: Van Nostrand Reinhold Company.

[17] N. W. and L. C. R. O’Neill, "Behavior of Bored Piles in Beaumont Clay, Jour," Proceedings, ASEC, vol. 98, No. SM, 1972.

[18] B. M. Das, Principles of Foundation Engineering. Thompson Brooks/cole, 2004.

[19] N. T. Singh, "Verification of pile load capacity using static pile load test Verifications of pile load capacity using static pile load test," 1st Int. Conf. Civ. Eng. Sustain. Dev. Oppor. Challenges, no. December 2016, pp. 136-140, 2016.

[20] ASTM D1143, “ASTM D 1143/D 1143M-07 Standard Test Methods for Deep Foundations Under Static Axial Tensile Load,” ASTM Int., vol. 07, no. Reapproved 2013, p. $15,2007$.

[21] L. D. Wesley, Mekanika Tanah. Jakarta: Badan Penerbit Pekerjaan Umum.

[22] P. S. Geoteknik, Insitu Testings and Soil Properties Correlations. Universitas Katolik Parahyangan.

[23] P. S. Geoteknik, Laporan Praktikum Penyelidikan Tanah. Fakultas Jurusan Teknik Sipil Universitas Katolik Parahyangan, 2015.

[24] A. BISHOP and D. J. HENKEL, "The Measurement of Soil Properties in the Triaxial Test,"Jan. 1957.

Performance Analysis Of "Toga" Foundation with Cap on Thick Soft Soil Based on Laboratory Models and Finite Element 
[25] Plaxis, “Tutorial Manual,” Plaxis 2D Connect Ed. V20, pp. 6-30, 2004.

[26] T. L. Gouw, "Common mistakes on the application of plaxis 2D in analyzing excavation problems," Int. J. Appl. Eng. Res., vol. 9, no. 21, pp. 8291-8311, 2014.

[27] B. K. Mazurkiewich, "Test Loading of Piles According to Polish Regulations," $R$. Swedish Acad. Eng. Sci. Comm. Pile Res. Rep. No.35, pp20, Stock., 1972.

[28] H. G. Poulos, "Pile testing and settlement prediction," Geotech. Spec. Publ., no. 227 GSP, pp. 630-649, 2012, doi: 10.1061/9780784412084.0044.

[29] M. Olgun, A. Hanati, and Y. Yengİnar, "Prediction of Pile Capacity from Field Loading Test Results by Using Different Methods," 3rd Int. Soil-Structure Interact. Symp. Turkey Predict., no. May, pp. 692-702, 2017. 